NBER WORKING PAPER SERIES

\title{
THE SHAPE OF TWENTIETH CENTURY ECONOMIC HISTORY
}

\author{
J. Bradford DeLong \\ Working Paper 7569 \\ http://www.nber.org/papers/w7569 \\ NATIONAL BUREAU OF ECONOMIC RESEARCH \\ 1050 Massachusetts Avenue \\ Cambridge, MA 02138 \\ February 2000
}

I would like to thank the NSF for financial support during the writing of this essay. This essay is a draft of the first chapter of a book tentatively entitled the History of the Twentieth Century Economy: Slouching Towards Utopia? My intellectual debts are vast, but my ten most weighty are to Lawrence Summers, Andrei Shleifer, Robert Barsky, David Cutler, Barry Eichengreen, Claudia Goldin, Lars Jonung, Larry Katz, Paul Krugman, David Landes, Peter Lindert, Christina Romer, Paul Romer, Richard Sutch, Peter Temin, Jan de Vries, Robert Waldmann, Jeffrey Weintraub, and Jeffrey Williamson (yes, I know that's twenty). The views expressed herein are those of the author and are not necessarily those of the National Bureau of Economic Research.

(C) 2000 by J. Bradford DeLong. All rights reserved. Short sections of text, not to exceed two paragraphs, may be quoted without explicit permission provided that full credit, including (C) notice, is given to the source. 
The Shape of Twentieth Century Economic History

J. Bradford DeLong

NBER Working Paper No. 7569

February 2000

\begin{abstract}
The history of the twentieth century can be summarized-excessively briefly-in five propositions: First, that the history of the twentieth century was overwhelmingly economic history. Second, that the twentieth century saw the material wealth of humankind explode beyond all previous imagining. Third, that because of advances technology, productivity, and organization-and the feelings of social dislocation and disquiet that these advances generated-the twentieth century's tyrannies were the most brutal and barbaric in history. Fourth, that the twentieth century saw the relative economic gulf between different economies grow at a rapid pace. Fifth and last, the economic policy-the management of their economies by governments-in the twentieth century was at best inept. Little was known or learned about how to manage a market or mixed economy.
\end{abstract}

\author{
J. Bradford DeLong \\ Department of Economics \\ U.S. Berkeley, \#3880 \\ Berkeley, CA 94720-3880 \\ and NBER \\ phone: (510) 643-4027 fax: (510) 642-6615 \\ delong@econ.berkeley.edu \\ http://econ161.berkeley.edu/
}




\section{The Shape of Twentieth Century Economic History}

\section{A. The millennial perspective ${ }^{2}$}

A thousand years from now the history that we know will have long since been boiled down to its bones. A thousand years hence history courses will spend as much time on the history of the twentieth century as we spend on the history of the tenth. ${ }^{3}$ Surveys will have at most one single two-hour session to spend on the entire twentieth century. In that one

\footnotetext{
${ }^{2}$ For an evocation of this millennial perspective, see the impressive book by Felipe Fernandez-Armesto (1996), Millennium: A History of the Last Thousand Years (New York: Touchstone Books: 0684825368). Femandez-Armesto is haunted by an image of the far future in which a crusader chainmail shirt and a CocaCola can both share a museum display case labeled "Second Millennium Artifacts."

${ }^{3}$ If there are history courses. If there are universities. There may not be. The university as an institution is only a thousand years old. The university as we know it today is not even two hundred years old. See Hilde de Ridder-Symoens, ed. (1991), A History of the University in Europe: Universities in the Middle Ages (Cambridge: Cambridge University Press: 0521361052); Frederick Rudolph (reissued 1991), The American College and University: A History (Athens, GA: University of Georgia Press: 0820312843); Henry Rosovsky (1991), The University: An Owner's Manual (New York: W.W. Norton: 0393307832).
} 
single session teachers will try to teach their students five ideas, and leave them with one single image.

The five ideas are:

- First, that the history of the twentieth century was overwhelmingly economic history: the economy was the dominant arena of events and change, and economic changes were the driving force behind changes in other areas of life in a way that had rarely been seen before.

- Second, that the twentieth century saw the material weal th of humankind explode beyond all previous imagining. We today--at least those of us who belong to the upper middle class and live in the industrial core of the world economy--are now far richer than the writers of previous centuries' utopias could imagine.

- Third, that because of advances technology, productivity, and organization--and the feelings of social dislocation and disquiet that these advances generated--the twentieth century's tyrannies were more brutal and more barbaric than in any previous century. Astonishingly, these tyrannies had their origins in economic discontents and found their expressions in economic ideologies. People killed each other by the millions over how economic life should be organized.

- Fourth, that the twentieth century saw the relative economic gulf between different economies grow at a rapid pace. Region by region and nation by nation, the world's material wealth became more unequally distributed in relative terms than ever before. 
- Fifth and last, that economic policy--the management of their economies by governments--in the twentieth century was at best inept. Little was known about how to manage a market or a mixed economy. Lessons learned from experience were quickly forgotten. There was an extraordinary gap between the powerful social-calculating and behavior-conditioning mechanisms that were twentieth century economies, and the ineptness with which these economies were managed.

These five ideas are the five themes of this book.

And the one image teachers a millennium hence will try to leave with their students?

Teachers will have no doubt that over the twentieth century taken as a whole humanity had made progress. And they will be right. The world today is closer to being a truly human world than it was back in the late nineteenth century. ${ }^{4}$ Today life expectancy at birth is some 67 years. Back in the late nineteenth century life expectancy at birth was under 40 years. Today only six percent of people die in their first year of life; back in the late nineteenth century roughly a quarter of all babies died. Today more than four-fifths of adults can read and write; back in the late nineteenth century only one-quarter of adults could read and write. ${ }^{5}$

\footnotetext{
${ }^{4}$ See Max Singer (1988), Passage to a Human World (Indianapolis: Hudson Institute: 1558130004).

${ }^{5}$ Today's statistics from United Nations (1999), Human Development Report 1999 (New York: Oxford University Press: 0195215613). The estimates for the late nineteenth century are my guesses--informed guesses, but still guesses. Even for the world economy's industrial core there is no deep and broad statistical picture of the economy and material life until the coming at the start of this century of the social insurance state. See Richard Sutch and Susan Carter, "Introduction" to Historical Statistics of the United States: Millennium Edition 0 .
} 
But this progress was accompanied by terror and death. Large chunks of the century were the greatest abattoirs ever seen. The progress towards utopia--toward a truly human world-cannot be described as a climb, or a sprint, or even a walk. Instead, the irresistible image is that of Yeats's rough beast slouching towards Bethlehem. ${ }^{6}$ The twentieth century was not what anyone had hoped that we would see. Humanity is closer to having material abundance than ever before. But will what happened along the way permanently mar our civilization? The roughness and brutality of our slouching progress towards utopia makes us wonder if we will get there. Material abundance and productive power are necessary, but not sufficient.

Each of these five themes deserves restatement at greater length:

\section{Twentieth Century History Was Economic History}

- That the history of the twentieth century was overwhelmingly economic history: the

\footnotetext{
${ }^{6}$ William Butler Yeats (1922), "The Second Coming" < last consulted 1999-12-21 at http://www.cwrl.utexas.edu/ benjamin/316kfall/316ktexts/yeatssecond.html $>$. "...Things fall apart; the center cannot hold;/ Mere anarchy is loosed upon the world,/ The blood-dimmed tide is loosed, and everywhere/ The ceremony of innocence is drowned;/ The best lack all conviction, while the worst Are full of passionate intensity./Surely some revelation is at hand;/ Surely the Second Coming is at hand.../The Second Coming!... /...now I know/ That twenty centuries of stony sleep/ Were vexed to nightmare by a rocking cradle, And what rough beast, its hour come round at last/ Slouches towards Bethlehem to be born?"
}

Others have been attracted to Yeats's image, most famously and impressively Joan Didion's (1979), Slouching Towards Bethlehem (New York: Noonday Presss: 0374521727), study of the 1960s counterculture. Robert Bork's (1996) Slouching Towards Gomorrah (New York: HarperCollins: 0060987197) is, in the words of amazon.com's anonymous reviewer "a bitter book from a passionale man who has very little good to say about the world he lives in" < last consulted 1999-12-21 at http://www.amazon.com/exec/obidos/ASIN/0060987197/>. 
economy was the dominant arena of events and change, and economic changes were the driving force behind changes in other areas of life in a way that had rarely been seen before.

In most centuries up until now the core of human history--the most interesting and significant parts--has at best a tangential relation to economic factors. The core of history is, instead, intellectual or religious or political. A history of the seventh or of the sixteenth centuries in western Eurasia and northern Africa must be primarily a religious history. The story of Muhammed and the origin and spread of Islam must be the main thread of the narrative written anyone who wants to tell the seventh-century story as it really happened, just as the Protestant Reformation and the fracture of westem Europe's church into warring factions must be the main thread of the sixteenth-century story in western Eurasia. ${ }^{7}$ The history of the fifteenth century is primarily cultural: in Europe the Renaissance, ${ }^{8}$ in China the cultural flourishing during the Ming Dynasty. ${ }^{9}$ The history of the late eighteenth and early nineteenth centuries must be primarily political: the American and French Revolutions and their consequences. ${ }^{10}$

\footnotetext{
${ }^{7}$ See Femand Braudel (1993), A History of Civilizations (New York: Penguin: 0140124896); J.M. Roberts (1993), A History of the World (Oxford: Oxford University Press: 0195210433).

${ }^{8}$ See Lauro Martines (1979), Power and Imagination: City-States in Renaissance Italy (New York: Knopf: (0801836433). This is not to say that long-term, slower-moving economic changes are not worth studying or were unimportant in shaping historical processes like the Renaissance. But the economy itself changed little during the century of the Renaissance. And what changes there were in the economy during that century are hard to link with the rest of its history. Hence the attempt of economic and social historians of pre-industrial ages to write history by depicting enduring structures rather than narrating sequences of events. See Fernand Braudel (1981), The Structures of Everyday Life, trans. rev. Sian Reynolds (New York: Harper and Row: 0060148454).

${ }^{9}$ See Jacques Gernet (1996), A History of Chinese Civilization, 2nd ed., trans. by J.R. Foster and Charles Hartman (New York: Cambridge University Press: 0521497817).

${ }^{10}$ See Robert R. Palmer (1971), The World of the French Revolution (New York: Harper and Row: 0049440098).
} 
In the past the core of history has been only tangentially related to economic factors because economic factors changed only slowly. The structure and functioning of the economy at the end of any given century was pretty close to what it had been at the beginning. The economy was more the background against which the action of a play takes place than a dynamic foreground character. Changes in humanity's economy--how people made, distributed, and consumed the material necessities and conveniences of their lives--required long exposures to become visible. ${ }^{11}$ By contrast religions, political systems, elite cultural configurations, and other aspects of history moved faster and further. The religious, cultural, and political lives of Lorenzo di Medici "Il Magnifico" in the fifteenth century were very different from the religious, cultural, and political lives of the lords of Etruscan Fiesole two thousand years before. The material life and living standards of Etruscan and Renaissance peasants were much more similar. ${ }^{12}$

But in the twentieth century things were very different. Then--and now--it is the economy that changes rapidly and fundamentally--while politics, culture, and religion exhibit more continuity.

In the twentieth century the pace of economic change was so great as to shake the rest of history to its foundation. For perhaps the first time the making and using the necessities

\footnotetext{
${ }^{11}$ See N.F.R. Crafts (1985), British Economic Growth during the Industrial Revolution (New York: Clarendon Press: 0198730675); Lynn Townsend White (1966), Medieval Technology and Social Change (New York: Oxford University Press: 0195002660).

${ }^{12}$ See Carlo Cipolla (194), Before the Industrial Revolution, 3rd ed. (New York: W.W. Norton: 0393311988); Jo-Ann Shelton (1998), As the Romans Did, 2nd edition (Oxford: Oxford University Press: 019508974X).
} 
and conveniences of daily life--and how production, distribution, and consumption changed--was the driving force behind a single century's history. ${ }^{13}$

[Picture: left-the harvest in Sicily, circa 1880; right-the harvest in Canada, circa 1998]

\section{The Twentieth Century Has Seen Wealth Explode}

- That the twentieth century saw the material wealth of humankind explode beyond all previous imagining. We today--at least those of us who belong to the upper middle class and live in the industrial core of the world economy--are now far richer than the writers of previous centuries' utopias could imagine.

There had been much technological progress before the industrial revolution, before the eighteenth and nineteenth century age of the spinning jenny, power loom, steam engine, coal mine, and iron works. ${ }^{14}$ The windmills, dikes, fields, crops, and animals of Holland

\footnotetext{
${ }^{13}$ There are only two possible competitors with the economy for the role of central stage of twentieth century history. You could write the twentieth century as the story of the development of science and technology--but that story is so intertwined with economic growth as to be, ultimately, nearly the same. You could write the twentieth century as the story of the fight of political democracy with fascism and communism. But once again that story is inextricably intertwined with the economic history of the century.

${ }^{14}$ The best is still David S. Landes (1969), The Unbound Prometheus (Cambridge: Cambridge University Press: 0521094186). See also Abbott P. Usher (1929), A History of Mechanical Inventions (New York: McGraw-Hill: 048625593X), David Mowery and Nathan Rosenberg (1998), Paths of Innovation: Technological Change in Twentieth Century America (Cambridge: Cambridge University Press: 0521641195).
} 
in 1700 made its economy very, very different indeed from that of those who had lived in the same marshes back in $700^{15}$; the ships that docked at the Chinese port of Canton had much greater range and the commodities loaded on and off them had much greater value in 1700 than in $700 .{ }^{16}$ But pre-industrial technological progress led to little improvement in the standard of living of the average human: improvements in technology and productive power by and large raised the numbers of the human race, not its material standard of living. ${ }^{17}$

The eighteenth and nineteenth centuries saw a faster change and a different kind of change. For the first time technological capability outran population growth and natural resource scarcity. By the last quarter of the nineteenth century the average inhabitant of a leading economies - a Briton, a Belgian, a Netherlander, an American, a Canadian, or an Australian - had perhaps three times the material wealth and standard of living of the typical inhabitant of a pre-industrial economy. ${ }^{18}$ The standards of living of the bulk of the population underwent a substantial, sustained, and unreversed rise in the eighteenth and nineteenth centuries-for perhaps the first time in a thousand, if not in seven thousand

\footnotetext{
${ }^{15}$ Jan de Vries and Ad van der Woude (1997), The First Modern Economy: Success, Failure, and Perseverance of the Dutch Economy, 1500-1815 (New York: Cambridge University Press: 0521578256).

${ }^{16}$ See Kenneth Pomeranz and Steven Topik (1999), The World that Trade Created New York: M.E. Sharpe: 0765602490); Kenneth Pomeranz (2000), The Great Divergence : China, Europe, and the Making of the Modern World Economy (Princeton: Princeton University Press: 0691005435).

${ }^{17}$ Massimo Livi-Bacci (1992), A Concise History of World Population (trans. Carl Ipsen) (Cambridge: Blackwell: 0631204555).

${ }^{18}$ Any such calculations are extremely, extremely shaky guesswork. For some guesses, see Paul Bairoch (1995), Economics and World History: Myths and Paradoxes (Chicago: University of Chicago Press: 0226034631); Angus Maddison (1992), Monitoring the World Economy (Paris: OECD); J. Bradtord DeLong (1999), "Estimating World GDP: 1 Million B.C.-Present"

$<\mathrm{http} / /$ econ161.berkeley.edu/TCEH/2000/World_GDP/Estimating_World_GDP.html $>$.
} 
years.

And material standards of living and levels of economic productivity have exploded in the twentieth century.

[Picture: left-working-class kitchen, circa 1880; right-working-class kitchen, circa 1998]

What took a worker in $\mathbf{1 8 9 0}$ an hour to produce takes an a worker in a leading economy today only about seven minutes to produce: by this measure we today have some eight times the material prosperity of our counterparts of a little more than a century ago. But such calculations substantially understate the boost to productivity and material prosperity that the past century has seen. We today are not just better at making the goods of a century ago. We today also have the new and powerful technological capability to make an enormously expanded range of goods and services: from videocassettes and antibiotics to airplane flights and plastic bottles.

[Picture: left-factory floor, circa 1880; right-factory floor, circa 1998]

We today would feel-we would be-enormously impoverished if by some mischance our money incomes and the prices of commodities remained the same, but if we were at the 
same time forbidden to use any commodity not produced in 1890.

This expansion in the range of what we can produce is an enormous additional multiplier of material well-being. Are we sixteen? thirty-two? sixty-four times as rich in a material sense as our predecessors in today's developed industrialized democracies were toward the end of the nineteenth century? The magnitude of the growth in material wealth has been so great as to make it nearly impossible to measure. ${ }^{19}$

This is the most important piece of the history of the twentieth century. As far as its ability to produce material goods is concerned, in the twentieth century the human race has passed through and left the realm of necessity - where providing basic food, clothing, and shelter took up the lion's share of economic productive potential. We have emerged into the realm of freedom: in which our collective production is no longer made up largely of the necessities of survival but of conveniences and luxuries. ${ }^{20}$

\footnotetext{
${ }^{19}$ The fact that we do measure it-or at least attempt to-is due to the cutting of the Gordian knot by Simon Kuznets in a somewhat arbitrary (yet productive) way. See Simon Kuznets (1966), Modern Economic Growth: Rate, Structure, and Spread (Princeton: Princeton University Press: 0300006462); Dan Usher (1979), The Price Mechanism and the Meaning of National Income Statistics (03132144662); Michael Boskin et al. (1996), Report of the Boskin Commission (Washington: GPO); Timothy Bresnahan and Daniel Raff (1997), The Economics of New Goods (Chicago: University of Chicago Press: $0226074153)$.

${ }^{20}$ Of course, as Donald Sassoon writes, the "so-called luxuries" are really "the necessities of the rich." See Donald Sassoon (1996), One Hundred Years of Socialism (New York: New Press: 1565843738), pp. 448-9. George Stigler would reply that this is the entire point: the entire point of economic growth is to generate new categories of "necessities" and the power to acquire and use them. See George Stigler, The Theory of Price.
} 


\section{Twentieth Century Tyrannies Were More Brutal}

- That because of advances technology, productivity, and organization--and the feelings of social dislocation and disquiet that these advances generated--the twentieth century's tyrannies were more brutal and more barbaric than in any previous century.

Astonishingly, these tyrannies had their origins in economic discontents and found their expressions in economic jdeologies. People killed each other by the millions over how economic life should be organized.

In the twentieth century governments and their soldiers have killed perhaps forty million people in war: either soldiers (most of them unlucky enough to have been drafted into the mass armies of the twentieth century) or civilians killed in the course of what could be called military operations.

But wars caused less than a third of the twentieth century's violent death toll.

Governments and their police have killed perhaps eighty million, perhaps one hundred and sixty million people in time of peace. Class enemies, race enemies, political enemies, economic enemies, imagined enemies have all been slaughtered. You name them, governments have killed them. And governments have killed them on a scale that could not previously have been imagined. If the twentieth century has seen the growth of material wealth on a previously-inconceivable scale, it has also seen human slaughter at a previously-unimaginable rate. ${ }^{21}$

\footnotetext{
${ }^{21}$ See Rudy Rummel (1994), Death by Government (New York: Transaction Publishers: 1560001453); I disagree with some of Rummel's estimates of the twentieth century's death toll (I think that his estimates for the Soviet Union are high by a factor of two, and that his estimates for Nazi Germany are low) - but he calls them like he sees them. On the three greatest tyrants of human history, my preferred sources are still the somewhat outdated William Shirer (1959), The Rise and Fall of the Third Reich (New York: Fawcett:
} 
[Picture: left-Nuremberg rally, 1934; right-Tien an Men Square]

Call those political leaders whose followers and supporters have slaughtered more than ten million of their fellow humans "members of the Ten-Million Club." All pre-twentieth century history may (but may not) have seen two members of the Ten-Million Club: Genghis Khan, ruler of the twelfth century Mongols, launcher of bloody invasions of Central Asia and China, and founder of China's Yuan Dynasty; ${ }^{22}$ and Hong Xiuquan, the mid-nineteenth-century Chinese intellectual whose visions convinced him that he was Jesus Christ's younger brother and who launched the Taiping Rebellion that tumed south-central China into a slaughterhouse for decades in the middle of the nineteenth century. ${ }^{23}$ Others do not make the list. Napoleon does not make it, and neither does Alexander the Great or Julius Caesar.

By contrast the twentieth century has seen perhaps five people join the Ten Million Club: Adolf Hitler, Chiang Kaishek, Vladimir Lenin, Joseph Stalin, and Mao Zedong. ${ }^{24}$ Hitler,

0449219771); the somewhat outdated Roy Medvedev (1976), Let History Judge (New York: Columbia University Presss: 0231063512); and Roderick MacFarquhar (1987), The Origins of the Cultural Revolution: The Great Leap Forward 1958-1960 (New York: Cambridge University Press: 0231057172). These sources seem to me to have a breadth and depth of vision that more than makes up for their failure to be completely up-to-date.

${ }^{22}$ Jeremiah Curtin (1996), The Mongols: A History (New York: Combined Books: 0938289659).

${ }^{23}$ Jonathan D. Spence (1996), God's Chinese Son: The Taiping Heavenly Kingdom of Hong Xiuquan (New York: W.W. Norton: 0393038440).

${ }^{24}$ On twenticth-century "democide," see R.J. Rummel (1997), Death by Government (New York: Transaction Publishers: 1560009276). 
Stalin, and Mao have credentials that may well make them the charter members of the Thirty Million Club as well-perhaps the Fifty Million Club. A regime whose hands are as bloody as those of the Suharto regime in Indonesia-with perhaps 450,000 communists, suspected communists, and others in the wrong place at the wrong time dead at its creation in $1965,{ }^{25}$ and perhaps 150,000 inhabitants of East Timor dead since the Indonesian annexation in the mid-1970 $\mathrm{s}^{26}$ - barely makes the twentieth century's top twenty list of civilian-massacring regimes.

[Picture: Rogue's Gallery: Political Leaders Who Have Presided Over the Twentieth Century's Biggest Massacres: Hitler, Stalin, Mao, Chiang KaiShek, and Admiral Tojo]

What does this-bloody - political and secret police history have to do with economic history? It seems at first glance that, while deplorable, it has little to do with the story of how people produced, distributed, and consumed the commodities needed and desired for their material well-being.

But it is not possible to write economic history without taking the bloody hands of twentieth century governments into account. First, the possibility that the secret police will

\footnotetext{
${ }^{25}$ Christopher Koch (reprint 1995), The Year of Living Dangerously (New York: Penguin: 0140065350).

${ }^{26}$ Geoffrey Gunn (1997), East Timor and the United Nations: The Case for Intervention (Red Sea Press: $1569020450)$.
} 
knock at your door and drag you off for torture and death is a serious threat to your material well-being. The seventeenth-century political philosopher Thomas Hobbes wrote that people are motivated by sticks and carrots: "the fear of violent death, and the desire for commodious living." ${ }^{27}$ In a century where the chance that a randomly-selected person will be shot or starved to death by his or her own government approaches two percent, the fact of large-scale political murder becomes a very important aspect of everyday life and material well being.

Second, the shooting or starvation was of ten part of the government's "management" of its economy: the stick used to compel the people to perform service or labor as the government wished. The economies of the Soviet Union in the 1930s and of China in the 1960s cannot be understood without understanding how mass terror was used as a worker discipline device. $^{28}$

Third, the twentieth century is unique in that its wars, purges, massacres, and executions have been largely the result of economic ideologies. Before the twentieth century people slaughtered each other for the other reasons. People slaughtered each other over theology: eternal paradise or damnation. People slaughtered each other over power. who gets to be top dog, and to command the material resources of society. But only in the twentieth century have people killed each other on a large scale in disputes over the economic organization of society.

\footnotetext{
${ }^{27}$ Thomas Hobbes (reprint 1982), Leviathan (New York: Viking: 0140431950).

${ }^{28}$ Roy Medvedev (1990), Let History Judge (New York: Columbia University Press: 0231063512); Robert Conquest (1968), The Great Terror: A Reassessment (New York: Oxford University Press: 0195071328); Roderick MacFarquhar (1987), The Origins of the Cultural Revolution: The Great Leap Forward: 19581960 (New York: Columbia University Press: 0231057172).
} 
When you think about it, killing people on a large scale over what social mechanisms should coordinate economic activity is profoundly stupid: we want social mechanisms that will work in the sense of delivering prosperity, progress, and a reasonably egalitarian distribution of income. Combinations of mechanisms that fail to accomplish this should be rejected; combinations that succeed should be approved; but the stakes are not large enough to justify large scale massacre.

The power of tyrants and leaders does not depend on the balance of command or market mechanisms in the economies that they govern. Fidel Castro would rule in Havana whether farmers are allowed to sell their crops in roadside stands, or whether they are prohibited from doing so-forced to sell to govemment monopoly bureaucracies. The power or personal status of leaders or the eternal salvation of peoples had little to do with twentieth century episodes as the Soviet collectivization of agriculture, the Cuban suppression of farmers' markets, the Khmer Rouge's forced emptying of Cambodia's cities, or the disaster of Mao's Great Leap Forward. All were in large part attempts to guide and shift the economy along the lines dictated by ideology.

Other twentieth century disasters had equally strong roots in economic ideology: it is hard to see World War II in the absence of Adolf Hitler's insane idee fixe that the Germans needed a better land-labor ratio-more "living space"-if they were to be a strong nation."

The last word should be Aleksandr Solzhenitsyn's: "The imagination and inner force of

${ }^{29}$ Adolf Hitler (1927), Mein Kampf (New York: Houghton Mifflin: 0395083621). 
Shakespeare's villains stopped short at ten or so cadavers, because they had no ideology.... It is thanks to ideology that it fell to the lot of the twentieth century to experience villainy on the scale of millions." ${ }^{30}$

\section{The Economic Gulf Between Nations Has Yawned Wide}

- That the twentieth century saw the relative economic gulf between different economies grow at a rapid pace. Region by region and nation by nation, the world's material weal th became more unequally distributed in relative terms than ever before.

Those economies relatively rich at the start of the twentieth century have by and large seen their material wealth and prosperity explode. Those nations and economies that were relatively poor have grown richer, but for the most part slowly. The relative gulf between rich and poor economies has grown steadily over the past century. Today it is larger than at any time in humanity's previous experience, or at least larger than at any time since only some tribes knew how to use fire. ${ }^{31}$

[Figure: left-street scene, Calcutta, circa 1998; right-street scene, Silicon Valley, circa 1998]

\footnotetext{
${ }^{30}$ Aleksandr Solzhenitsyn (1979), A World Split Apart (Cambridge: Harvard University Press: 0060140070).

${ }^{31}$ Lant Pritchett (1997), “Divergence, Bigtime," Journal of Economic Perspectives 11:3 (Summer), pp. 3 17.
} 
This glass can be viewed either as half empty or as half full. It is half empty because we live today in the most unequal world ever. It is half full because most of the world has already made the transition to sustained economic growth; most people live in economies that (while far poorer than the leading-edge post-industrial nations of the world's economic core) have successfully climbed onto the escalator of economic growth and thus the escalator to modernity. ${ }^{32}$ The economic transformation of most of the world is less than a century behind the of the leading-edge economies-only an eyeblink behind, at least from the millennial perspective (even though the millennial perspective is one that human beings can adopt only when contemplating the long-dead past).

On the other hand, one and a half billion people live in economies that have not made the transition to economic growth, and have not climbed onto the escalator to modernity. It is hard to argue that the median inhabitant of Africa has a higher real income than his or her counterpart of a generation ago. ${ }^{33}$

From an economist's point of view, the existence, persistence, and increasing size of large

\footnotetext{
${ }^{32}$ A phrase that was - as far as I know - coined by U.S. Treasury Secretary and former World Bank chief economist Lawrence Summers.

${ }^{33}$ See Robert Bates (1984), Markets and States in Tropical Africa: The Political Economy of Agricultural Policies (Berkeley: University of California Press: 0520052293); Robert Summers and Alan Heston, "The

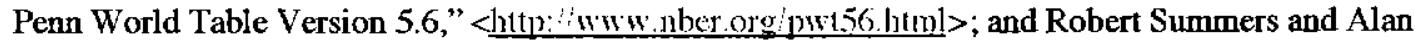
Heston (1991), "The Penn World Table (Mark 5): An Expanded Set of International Comparisons," Quarterly Journal of Economics 106:9 (May), pp. 327-68. On the other hand, the average inhabitant of Africa today has a longer life expectancy (even with AIDS) and is much better educated than a generation ago. See United Nations (1999), Human Development Report (New York: Getty Center: 0195215621).
} 
gaps in productivity levels and living standards across nations seems bizarre. We can understand why pre-industrial civilizations had different levels of technology and prosperity: they had different exploitable nature resources, and the diffusion of new ideas from civilization to civilization could be very slow. Such explanations do not apply to the world today.

The source of the material prosperity seen today in leading-edge economies is no secret: it is the storehouse of technological capabilities that have been invented since the beginning of the industrial revolution. This storehouse is no one's private property. Most of it is accessible to anyone who can read. Almost all of the rest is accessible to anyone who can obtain an M.S. in Engineering.

Because of modern telecommunications, ideas today spread at the speed of light. Governments, entrepreneurs, and individuals in poor economies should be straining every muscle - should in fact have long ago strained every muscle- to do what Japan began to do in the mid-nineteenth century: acquire and apply everything in humanity's storehouse of technological capabilities.

This "divergence" in living standards and productivity levels is another key aspect of twentieth century economic history: economies are, by almost every measure, less alike today than a century ago in spite of a century's worth of revolutions in transportation and communication.

Moreover, there seems to be every reason to fear that this "divergence" in living standards and productivity levels will continue to grow in the future. A number of factors have kept 
economic growth slow in today's poor countries in the past: high rates of population growth that restrict growth in the capital-output ratio, high relative prices of capital goods that constrain investment, governments that (like most governments throughout history) take the short view in an attempt to maximize chances of survival and the perquisites of office, and traditional elites (religious and cultural) that fear what they will lose from a richer country more integrated into the twenty-first century world. These factors are still operating today, and likely to operate in the future as well.

This is a potential source of great danger, because today's world is sufficiently interdependent-politically, militarily, ecologically - that the passage to a truly human world requires that we all get there at roughly the same time. ${ }^{34}$

\section{Political Management of Economic Life Has Been Inept}

- That economic policy--the management of their economies by governments--in the twentieth century was at best inept. Little was known about how to manage a market or a mixed economy. Lessons learned from experience were quickly forgotten. There was an extraordinary gap between the powerful social-calculating and behavior-conditioning mechanisms that were twentieth century economies, and the ineptness with which these economies were managed.

\footnotetext{
${ }^{34}$ For the phrase "passage to a human world," see Max Singer (1988), Passage to a Human World (Transaction Publishers: 0887382592), which gives an optimistic-and-realistic projection of how things might go right. His argument is Implicitly undermined in parts by Max Singer and Aaron Wildavsky (1996), The Real World Order (Chatham House: 1566430313).
} 
The twentieth century has seen the century-long economic disaster of communism, and the quarter-century-long disaster of fascism. It has also seen many governments that appear singularly inept at managing market economies: inept at coping with economic shocks that threaten to cause mass unemployment or raging hyperinflation. Some of it is because twentieth century economists did not know what to prescribe: the history of economic policy reads like alchemy, not chemistry. Often proposed remedies made economic problems worse. $^{35}$

\section{[Picture: Crowds outside the New York Stock Exchange during the Crash of 1929]}

Some of it is that politicians did not like to follow their economists' advice, or at least sought for a more complaisant set of economists who would give advice that would be more politically pleasing and palatable to follow. Some of it is that those who do not remember the past are condemned to repeat it-and the rest of us are condemned to repeat it with them. ${ }^{36}$

The twentieth century economy has been a tremendously powerful, efficient, and

\footnotetext{
${ }^{35}$ Most catastrophically in the Great Depression, when worldwide economic policies seemed as if geared to magnify the size of the Depression as much as possible. See J. Bradford De Long (1998), "Fiscal Policy in the Shadow of the Great Depression," in Michael Bordo, Claudia Goldin, and Eugene White, eds. (1998), The Defining Moment: The Great Depression and the American Economy in the Twentieth Century (Chicago: University of Chicago Press: 0226065898), pp. 67-86; Barry J. Eichengreen (1992), Golden Fetters: The Gold Standard and the Great Depression (Oxford: Oxford University Press: 0195101138).

${ }^{36}$ As Santayana did not say. See George Santayana (reprint 1995), The Birth of Reason and Other Essays (New York: Columbia University Press: 0231102771).
} 
productive social mechanism - the market system. Yet few, or few of those in power, have known how to operate or fix it. Moreover, learning does not appear to take place-or if it does take place, it does not take place at more than a glacial pace. The inescapable image is of an ocean liner crewed and steered by chimpanzees.

The failures and half-successes of economic policy logether make up another key facet of twentieth century economic history: how governments have managed or mismanaged their economies, and how knowledge of how the economic system works has been painfully gained and then painfully lost.

\section{B. Organization}

\section{Other Themes}

There are other themes as well: shifts in the distribution of relative wealth and economic power from rich to middle-class and back again, as the wave of social democracy sloshes across the industrial economies in the twentieth century; ${ }^{37}$ the Great Depression, the defining moment of twentieth century economic history $;{ }^{38}$ the rise to economic preeminence of the United States; and forthcoming challenges to America's role at the leading

\footnotetext{
${ }^{37}$ Peter Hall (1989), The Political Power of Economic Ideas: Keynesianism Across Nations (Princeton: Princeton University Press: 0691023026); Donald Sassoon (1996), 100 Years of Socialism (New York: New Press: 1565843738); T.H. Marshall (1950), Citizenship and Social Class and Other Essays (Cambridge: Cambridge University Press: ).

${ }^{38}$ Cite to Michael Bordo, Claudia Goldin, and Eugene White, eds. (1998), The Defining Moment: The Great Depression and the American Economy in the Twentieth Century (Chicago: University of Chicago Press).
} 
technological and econo-cultural edge as "the furnace where the future is being forged."

All these other themes are important strands in twentieth century economic history. But from the perspective of a millennium, the most important aspects of twentieth century economic history cannot help but be those five sketched above: the dominance of economic events in twentieth century history; the tremendous surge of material prosperity; the coupling of productive power and economic ideology with mass murder; the bizarrely uneven distribution of economic growth and prosperity around the world; and the failure of economic policy to advance from the stage of alchemy to chemistry.

\section{Structure of the book}

The first part of this book tries to take such a millennial perspective: a chapter on each of the principal themes of the economic history of the twentieth century.

Only afterwards do I drop back into narrative. The narrative begins by trying to paint a picture of the state and trajectory of the world economy at the end of the nineteenth century. It skates briefly over developments up through World War I, focusing on how the first truly global economy of the pre-World War I period-the first economy in which transport

\footnotetext{
${ }^{39}$ See David Hounshell (1984), From the American System to Mass Production (Baltimore: Johns Hopkins: 080183158X); H.J.Habakkuk (1962), American and British Technology in the Nineteenth Century (Cambridge: Cambridge University Press); the description of the United States as the "furnace where the future is being forged" comes from Leon Trotsky (1929), My Life (0873481445).
} 
costs were low enough for trade to have a powerful impact on every portion of the globe-functioned. It then turns to the attempts to rebuild and reorganize the world economy in the aftermath of World War I, and their catastrophic failure. It traces the causes, progress, and consequences-economic and political - of the disaster that was the Great Depression.

The narrative then briefly treats the economic consequences of World War II before marveling at the job of reconstruction done in the aftermath of Adolf Hitler's war. It continues to marvel at the pace of the subsequent Great Keynesian Boom of the generation after World War II. It then focuses on the more troubled economic period since 1973 or so. And, last, it peers dimly into the future of the human economy.

\section{Focus}

This is a history of the global economy in the twentieth century: of the events and processes of the network of trade, investment, and communication that spanned the globe at the start of the twentieth century. Thus the focus throughout is on the industrial core: the rich nations, originally grouped around the North Atlantic Ocean, that have been at the leading edge of economic development, structural change, and technological advance in this century. These are the economies that traded, invested, and communicated the most. This is what I know best, and am more than half-qualified to write about. But I hope that I have paid due attention to the economic history of the rest of the world as it became increasingly 
enmeshed in the global economy throughout the twentieth century.

The level of analysis attempts to be neither "history from above" nor "history from below" but rather "history from beside."

"History from above" tells of the doings of kings, princes, and general secretaries in marble-floored buildings and green silk-covered rooms. "History from below" tells of what ordinary people ate and wore and thought.

Neither is adequate.

The focus on the Duke of This or the Earl of That found in "history from above" is a trivially small part of the history. How did people try to get enough to eat? Were people well enough nourished for young women to easily reach puberty? How did patterns of daily life change? The answers to these questions tell us more about the history, and are intrinsically at least as interesting, as are stories of assassinations and intrigue at the courts of Tiberius Claudius Nero Caesar Germanicus (the Roman Emperor Claudius) or of Josef Vissarionovich Djugashvili (the Soviet General Secretary Stalin). In the long run menarche-whether the people are well-enough nourished for women to go through puberty at an early age-is more important to know about than monarchy. How billions of people lived and live their lives is more important than the maneuvers and problems of the few who sit at the very top of the pyramids of human social organization. The difficulties created by the affair of the Chancellor with the Queen Mother are less important - with the proviso that at many times and places the history of monarchy had had important 
implications for the average age at menarche. ${ }^{40}$

But the patterns of daily life of the general population and how they change make little sense if they are divorced from any consideration of high politics and changing technology. For high politics and changing technology shape and change how real people live-not only whether they live or die at the hands of thugs-with-guns, but what kind of life they are able to live.

It is a commonplace that each generation writes its own history: each generation is interested in different facets of the past, and a given work of history often tells as much about its own present in which it was written as about the past that it purports to analyze. This commonplace is not completely true. One reason to write history is that it is entertaining: the stories of what people actually did and suffered that historians tell are some of the greatest stories on earth. The twentieth century has more than its share of such narratives.

A second reason for history is simply to gratify curiosity, which may or may not be related to the circumstances of the writer's or the reader's era.

Yet there is a third powerful motive: the search for "lessons" of the past for the present. Today, in the wealthy and industrialized countries of the world, our principal concerns are with the creation and maintenance of liberty and prosperity, and with understanding what

\footnotetext{
${ }^{40}$ For a strident declaration that the history of monarchy is more important than the history of menarche (though I could find no clear explanation of why), see Gertrude Himmelfarb (1987), The New History and the Old (Cambridge: Harvard University Press: 0674615816).
} 
our (comparative) liberty and (relative) prosperity has transformed us. Other audiences in other places and other times have had different concerns: how to ensure the triumph of the "true" theology, how to conquer one's neighbors, or how elites can maintain political power or economic and social dominance.

This history is written from our particular turn-of-the-twenty-first-century viewpoint: it tells the story of the twentieth century as the story of liberty and prosperity-the partial escapes from (and at time and places the falls back down into) servitude and poverty. This particular grand narrative is an interesting one to write because it is of great interest to almost everyone, and because its ending is not clear. There is no logic immanent in history unfolding itself: nothing except our own and our descendants efforts and struggles can make this particular grand narrative have a happy rather than a tragic conclusion.

I think that this is the most interesting take on the history of the wentieth century. Others are free to disagree. ${ }^{41}$ And the fact that others are free to disagree, and value that freedom, reinforces my belief that my particular grand narrative is a felicitous one to tell. ${ }^{42}$

\footnotetext{
${ }^{41}$ For example, consider Eric Hobsbawm (1994), The Age of Extremes (New York: Vintage). He writes the history of the twentieth century as the tragedy of Communism: its birth, rise, self-destruction, and fall. I see the rise and fall of world communism as an important subplot of twentieth century history, but not (save for those killed in the basement of Lubyanka Prison, those starved to death during the Great Leap Forward, and their fellows for whom it was the most important thing in their lives) the main plot. In this twentieth century we both have the material resources and power to write our interpretations, and we have the freedom to argue that our particular vision is the most interesting, powerful, and insightful. There are many ways in which the (wentieth century could have turned out in which we would have lacked the material resources to write, or the freedom to make our writings public.

${ }^{42}$ For visions of the future in which people are most definitely not able to disagree with the particular grand narrative that their rulers choose to make sense of history, see Yevgeny Zamyatin (1924), We (New York: Avon: 0380633132); Aldous Huxley (1932), Brave New World (New York: HarperCollins: 0060809833); George Orwell (1948), 1984 (New York: Knopf: 0679417397); Arthur Koestler (1940), Darkness at Noon (New York: Bantam: 0553265954).
} 
One of the glories of the history of the twentieth century is that-although it has an extremely depressing middle-it seems to be moving more toward a (relatively) happy than a tragic ending: this is a (relatively) free and prosperous country, and (compared to the past) a relatively free and prosperous world. 